\title{
Characterization and Immobilization of Purified Alliinase Produced from Shallots
}

\section{Qinzhu Zeng ${ }^{1}$, Aihui Veng ${ }^{1}$, Linghui Kong ${ }^{2}$ and Shan $\mathrm{He}^{1 *}$}

${ }^{1}$ Department of Food Science, School of Chemistry and Chemical Engineering, Guangzhou University, China

${ }^{2}$ Huixiangyuan Biotech Pty Ltd, Guangdong, China

"Corresponding author: Shan He, Department of Food Science, School of Chemistry and Chemical Engineering, Guangzhou University, China, Tel: +8618922255003; E-mail: he0091@gmail.com

Received date: July 20, 2017; Accepted date: July 30, 2017; Published date: Aug 05, 2017

Copyright: @ 2017 Zeng Q, et al. This is an open-access article distributed under the terms of the Creative Commons Attribution License, which permits unrestricted use, distribution, and reproduction in any medium, provided the original author and source are credited.

\begin{abstract}
In this study, Alliinase extracted and purified from shallots was comprehensively examined. Its molecular weight was determined as $50 \mathrm{kDa}$, and its optimal working conditions were identified as $\mathrm{pH} 8$ and $40^{\circ} \mathrm{C}$. Its activity was significantly and positively affected by the metals $\mathrm{K}^{+}, \mathrm{Na}^{+}, \mathrm{Ga}^{2+}, \mathrm{Mg}^{2+}$ and $\mathrm{Fe}^{2+}$. Purified Alliinase was immobilized by alginate and the optimized conditions for this process were: a sodium alginate concentration of $2.5 \%$, a $\mathrm{CaCl}_{2}$ concentration of $4.0 \%$, a Glutaraldehyde concentration of $0.75 \%$, and a ratio of sodium alginate solution and Alliinase solution (by volumn) of $4: 3$. The ability for free Alliinase and immobilized Alliinase to release flavours from shallots was compared. It was found that immobilization did not compromise Allinase's flavor releasing ability. They both released 36 flavouring chemicals from the flavouring precursor, with a similar ratio. This study provided fundamental information for further commercial development of Alliinase produced from shallots.
\end{abstract}

Keywords: Alliinase; Metals; Immobilization; Optimization; Flavour releasing

\section{Introduction}

Shallots originated in Central Asia, and spread across East Asia, South East Asia and the Mediterranean. They have been broadly used as a delicacy in the traditional cuisines of these regions due to their spicy taste and fragrant smell [1]. Besides this, the extracted bioactive components from shallots, which possess health benefits, have also been widely reported. These include but are not limited to: flavone which has anti-cancer effects, amino acids which prevent myocardial infarction, and water-soluble fibres which have anti-hypertension properties [2].

It has been recognized that flavour release from shallots is associated with Alliinase. During the cooking process, Alliinase is released from vacuoles and catalyses alliin, the precursor to flavouring components, to form the flavouring components of garlicin, pyruvic acid and amine [3]. Therefore, extraction and purification of Alliinase is the key to develop shallot-flavoured condiments.

Alliinase was first extracted from onions by Stoll and Seeback in 1949. Following this achievement, different purification methods for Alliinase have also been developed. Using the purified Alliinase extracted by Stoll and Seeback as a benchmark, Nock used affinity chromatography on concanavalin A-Sepharose $4 \mathrm{~B}$ to produce 6.5 times more purified Alliinase [4]. Nock and Mazelis purified Allinase to homogeneity ( 7.5 times more purified) by using chromatography steps on hydroxylapatite, on an anion exchanger, and on a chromate focussing medium [5]. The purified Alliinase has also been further studied for its molecular weights and enzymatic kinetics (Figure 1). Yan et al. used SDS-PAGE to determine that the molecular weight of Alliinase is $53 \mathrm{kDa}$. However, these studies used onion as the raw material [6]. Similar studies of Alliinase extracted from shallots have not been studied yet. 
Page 2 of 8

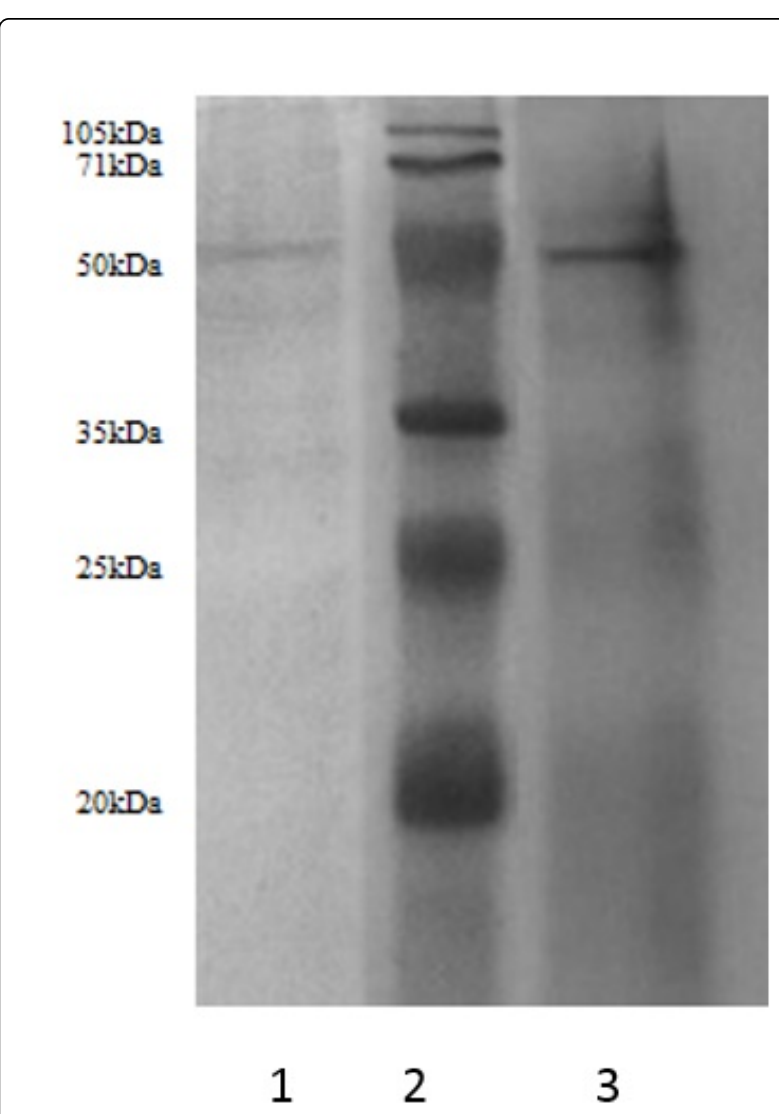

Figure 1: Molecular weights of Alliinase after extraction and purification. Molecular weights of Alliinase after purification. Line 2: Marker. Line 3: Molecular weights of Alliinase after extraction

In order to extend shelf life and stability, immobilized enzymes have been broadly used. An immobilized enzyme is an enzyme attached to an inert, insoluble material. This can provide increased resistance to changes in conditions such as $\mathrm{pH}$ or temperature. It also allows enzymes to be held in place throughout a reaction, following which they are easily separated from the products and may be used again. This technology has been used for producing detergent and lactosefree milk. Recently, several studies on immobilized Alliinase have also been carried out. Ko et al. immobilized Alliinase extracted from onion bysodium alginate [7]. They found out that the enzyme activity of immobilized Alliinase increased $30 \%$ at a temperature of $60^{\circ} \mathrm{C}$. Zhou and Wang tagged the immobilized Alliinase on a chitin-based material [8]. They reported that enzyme activity was $10 \%$ less, after using 10 times. However, studies on immobilized Alliinase are only in the initial stages, and more studies in this field should be conducted in the future.

The aim of this study was to develop a method to extract and purify Alliinase from shallots. Furthermore, the process of immobilizing Alliinase was also optimized based on the purified Alliinase produced in this study. Last but not least, the effects of both free and immobilized Alliinase on the release of flavouring components were determined. This study has not only filled the knowledge gap about Alliinase obtained from shallots, but has also provided scientific guidance for the development of shallot-flavoured food products in the future.

\section{Materials and Methods}

\section{Materials}

Chemicals were purchased from Sigma-Aldrich Pty. Ltd (Shanghai, China). The centrifuge was purchased from Luxiang, Pty, Ltd (Changsha, Hunan, China). The spectrometer was purchased from Cole-Parmer Instrument Company (London, UK). The homogeniser was purchased from Angyi Instrument Pty, Ltd (Shanghai, China). The laboratory microwave oven was purchased from Yuejing, Pty, Ltd (Shanghai, China). The rotary evaporator was purchased from Heidolph Instruments GmbH and Co.KG (Schwabach, Germany). Gas chromatography-mass spectrometry was purchased from Agilent Technologies (Santa Clara, California, U.S.A).

\section{Extraction of Alliinase from shallots}

One hundred grams of shallot were peeled off, crushed, then mixed with $200 \mathrm{ml}$ of phosphate buffer. The mixture was homogenized in a bio-homogenizer at a speed of 25,000 for $1 \mathrm{~min}$. The homogenized mixture was filtered 3 times by 3-layers of cheesecloth, then centrifuged at $4^{\circ} \mathrm{C}(10,000 \mathrm{~g}, 30 \mathrm{~min})$. The supernatant, which was the Alliinase extract, was collected, sealed and stored at $4^{\circ} \mathrm{C}$ until use.

\section{Purification of the extracted Alliinase using Sephadex G75}

The extracted Alliinase was purified using Sephadex G75 following the method of Islam with slight modifications [9]. The extracted Alliinase was centrifuged at $17,000 \mathrm{~g}$ for $15 \mathrm{~min}$ at $4^{\circ} \mathrm{C}$. The liquid after centrifugation was loaded on Sephadex G-75 gel filtration chromatography columns $(2.0 \mathrm{~cm} \times 50 \mathrm{~cm}$; Pharmacia $)$, previously equilibrated with $200 \mathrm{mM}$ ammonium acetate, at a $\mathrm{pH}$ of 6.8 , and eluted under the same conditions. The flow rate was $3 \mathrm{ml} / \mathrm{min}$ using a Bio-Rad 2110 fraction collector and the elution of the proteins was monitored at $280 \mathrm{~nm}$ by an ultraviolet detector.

\section{Molecular weight distributions of extracted and purified Alliinase}

Molecular weight distributions of the extracted and purified Alliinase were analysed by SDS-electrophoresis following the method of $\mathrm{He}$ et al. with a slight modification [11]. Concentrations of loading sample solutions were adjusted to $3.3 \mathrm{mg} / \mathrm{mL}$ measured by the BCA method. Then $15 \mu \mathrm{L}$ of each protein solution was mixed with $5 \mu \mathrm{L} 4 \times$ SDS-PAGE sample loading buffer (40\%(v/v) glycerol, $4 \%(\mathrm{v} / \mathrm{v})$ lithium dodecyl sulfate, $4 \%(\mathrm{v} / \mathrm{v})$ Ficoll-400, 0.8M triethanolamine-C1 $\mathrm{pH}$ 7.6, $0.025 \%(\mathrm{w} / \mathrm{v})$ phenol red, $0.025 \%(\mathrm{w} / \mathrm{v})$ (Commassie G250, $2 \mathrm{mM}$ EDTA disodium), followed by heating in a hot water bath at $90^{\circ} \mathrm{C}$ for $3 \mathrm{~min}$ before loading into wells on the gel. A dual colour stain protein molecular weight marker ranging from 10 to $250 \mathrm{kDa}$ (Precision plus protein standards, Bio-Rad Laboratories, Inc., CA, USA) was used to determine the molecular weight of protein samples. A gradient gel with a concentration from $4 \%(\mathrm{w} / \mathrm{v})$ to $20 \%(\mathrm{w} / \mathrm{v})$ was placed into a gel tank filled with $4 \mathrm{mM}$ MOPS gel buffer (200 mM MOPS, pH 7.0, $80 \mathrm{mM}$ sodium acetate, and $10 \mathrm{mM}$ EDTA, $\mathrm{pH} 8.0$ ) and then samples were loaded into $20 \mu \mathrm{L}$ wells. The get tank was connected to a power pack supplying a voltage that increased to $200 \mathrm{~V}$ with a current between 80 and $90 \mathrm{~mA}$ for $90 \mathrm{~min}$. Subsequently, the gel was stained with Coomassie Blue for $1 \mathrm{hr}$ and destained with $100 \mathrm{ml}$ destain solution (40\%(v/v) MilliQ water, 50\%(v/v) methanol and $10 \%(\mathrm{v} / \mathrm{v})$ glacial acetic acid) for 2 hrs. 


\section{Measurement of Alliinase activity}

The enzyme activity of Alliinase was measured by the method developed by Lawson et al. with minor modifications [12]. The Alliinase activity was expressed as the formation of pyruvate. An Alliinase sample of $1.0 \mathrm{~mL}$ was added into $1.0 \mathrm{~mL}$ of standard reaction mixture containing $60 \mathrm{mmol} \mathrm{L}^{-1}$ sodium phosphate buffer at $\mathrm{pH} 6.5,25$ $\mu \mathrm{mol} \mathrm{L}{ }^{-1}$ pyridoxal-5-phosphate (PLP), and $6 \mathrm{mmol} \mathrm{L}^{-1}$ alliin as the substrate. The enzymatic reaction was incubated at $25^{\circ} \mathrm{C}$ for $5 \mathrm{~min}$. The reaction was terminated by adding $2 \mathrm{~mL} 10 \%(\mathrm{v} / \mathrm{v})$ trichloroacetic acid. The reaction mixture was then centrifuged at $10000 \times \mathrm{g}$ for $10 \mathrm{~min}$ at $4^{\circ} \mathrm{C}$ to remove the precipitated protein. The supernatant was collected and assayed for pyruvate concentration. A volume of $1.0 \mathrm{~mL}$ of 50 mmol L-1 2,4-dinitrophenylhydrazine was then added into the supernatant and incubated at $25^{\circ} \mathrm{C}$ for $5 \mathrm{~min} .5 \mathrm{ml}$ of $2.5 \mathrm{~mol} \mathrm{~L}^{-1}$ $\mathrm{NaOH}$ was added and incubated at $25^{\circ} \mathrm{C}$ for $10 \mathrm{~min}$. The absorbance at
$520 \mathrm{~nm}$ was determined using a UV spectrophotometer UV-1800 (Shimadzu, Tokyo, Japan) at ambient temperature. The pyruvate concentration was calculated according to the standard curve of pyruvate. One unit of alliinase activity was defined as the amount of enzyme, which releases $1 \mathrm{nmol}$ pyruvate $\mathrm{min}^{-1}$.

\section{Determination of the optimum working conditions ( $\mathrm{pH}$ and temperature) for purified Alliinase}

For the test for optimum $\mathrm{pH}$ of purified Alliinase, nine tubes of 1 $\mathrm{mL}$ substrate of $6 \mathrm{~mol} / \mathrm{L}$ alliin was mixed with $1 \mathrm{~mL}$ Alliinase solution. The reaction lasted for $5 \mathrm{~min}$ at $40^{\circ} \mathrm{C}$ at $\mathrm{pH}$ ranged from 3 to 11 respectively. After the reactions, the Alliinase activity at the different $\mathrm{pH}$ levels was measured using the aforementioned method in section 2.5. The $\mathrm{pH}$ with the highest Alliinase activity was regarded as the optimum $\mathrm{pH}$ for Alliinase (Figure 2).

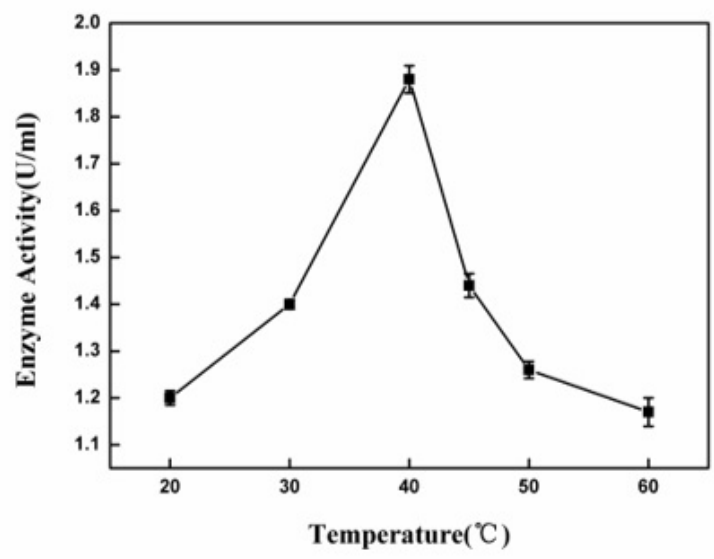

(A)

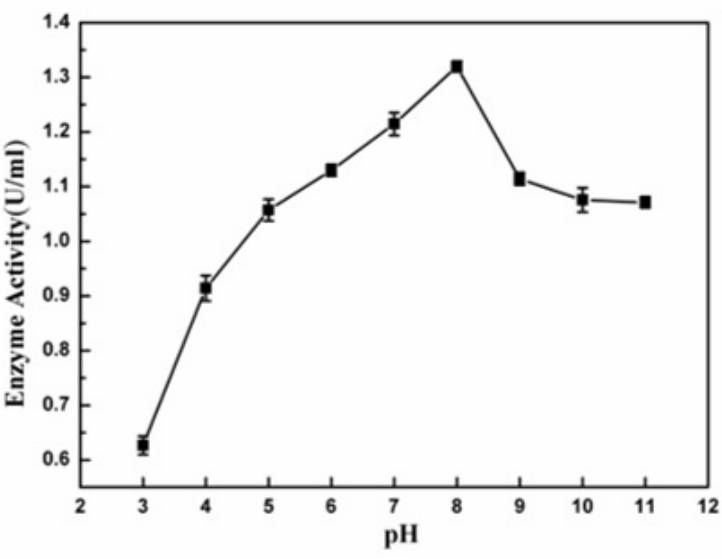

(B)

Figure 2: Determination of the optimum working conditions (temperature and $\mathrm{pH}$ ) of Alliinase extracted from shallots. A-Temperature, B-pH.

For the test of optimum temperature for purified Alliinase, six tubes of $1 \mathrm{~mL}$ substrate of $6 \mathrm{~mol} / \mathrm{L}$ Alliin were mixed with $1 \mathrm{~mL}$ Alliinase solution. The reaction lasted for $5 \mathrm{~min}$ at a $\mathrm{pH}$ of 7 at temperatures of $20^{\circ} \mathrm{C}, 30^{\circ} \mathrm{C}, 40^{\circ} \mathrm{C}, 50^{\circ} \mathrm{C}$ and $60^{\circ} \mathrm{C}$, respectively. After the reactions, the Alliinase activity at the different $\mathrm{pH}$ levels was measured using the aforementioned method in section 2.5. The $\mathrm{pH}$ with the highest Alliinase activity was regarded as the optimum $\mathrm{pH}$ for Alliinase.

\section{Determination of the kinetic parameters of purified Alliinase}

The Michaelis-Menten kinetic constants; the maximum reaction rate $\left(\mathrm{V}_{\max }\right)$ and Michaelis-Menten Constant $(\mathrm{Km})$ of the purified alliinase were determined using the different concentrations of alliin (1-10 $\mathrm{mM})$, the substrate for Alliinase. All the reactions were undertaken at the determined optimum working conditions of Alliinase. The kinetic parameters were determined using a LineweaverBurk plot. $\mathrm{Km}$ and $\mathrm{V}_{\max }$ were calculated using Graph Pad PRISM software version 5.0 (Figure 3). 


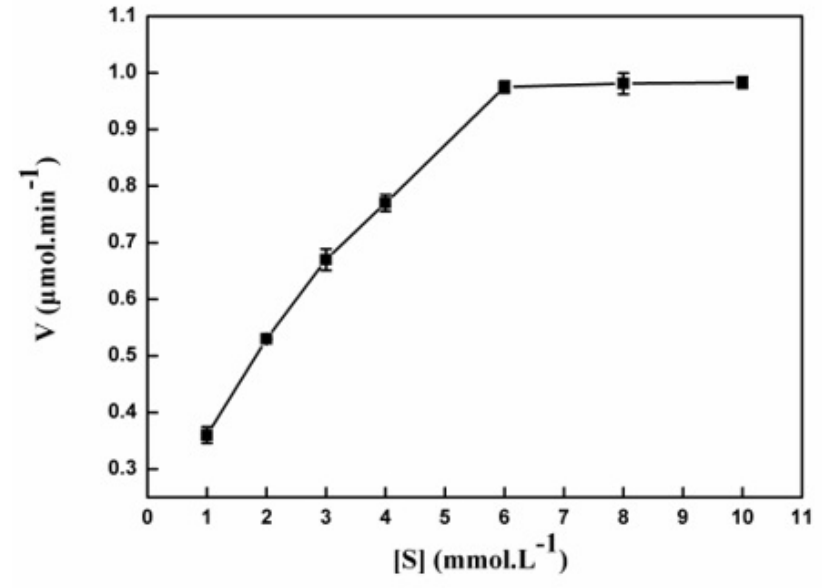

(A)

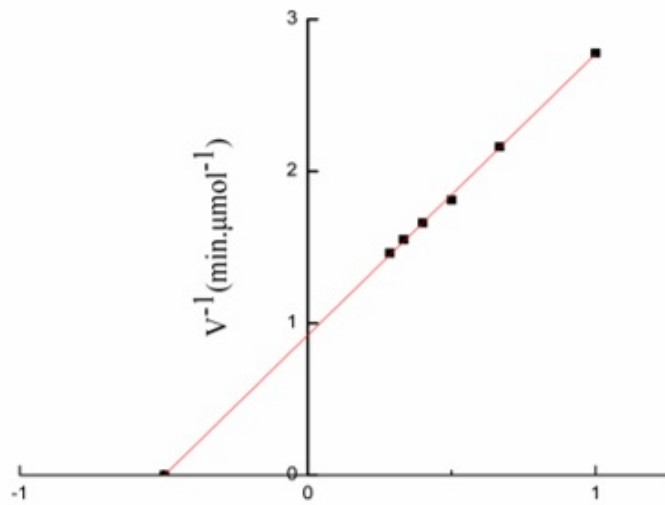

$[\mathrm{S}]^{-1}\left(\mathrm{~L} \cdot \mathrm{mmol}^{-1}\right)$

Figure 3: Kinetic analysis of Alliinase produced from shallots. A-Effect of substrate concentration on Alliinase activity, B-Lineweaver-Burk double reciprocal plot for kinetic analysis of Alliinase produced from shallots.

\section{The effect of metal on the enzyme activities of Alliinase}

The effect of different metals on alliinase activity was assessed by adding each metal ion to the reaction mixture and assaying for its activity. The method followed Schwinner and Mazelis with slight modifications [11]. The final concentrations of the metal salts in the reaction mixture were maintained at $1 \mathrm{mM}$. The metals used were chloride salts of $\mathrm{K}^{+}, \mathrm{Na}^{+}, \mathrm{Ca}^{2+}, \mathrm{Mg}^{2+}$ and $\mathrm{Fe}^{3+}$. The enzyme was incubated in the presence of various metal ions and chemicals for $1 \mathrm{~h}$ and relative enzyme activity (\%) was determined.

\section{Optimization of the Alliinase immobilization process}

An orthogonal experiment was used for optimization of the Alliinase immobilization process. Four factors, which were the sodium alginate concentration, the $\mathrm{CaCl}_{2}$ concentration, the Glutaraldehyde concentration and the ratio of sodium alginate and Alliinase by volumn, were selected as the most important factors for this optimization. A L9 (34) orthogonal factor table (Table 1) was designed to demonstrate all different levels of factors for this optimization. The ratio of immobilization was selected as the response.

\begin{tabular}{|c|c|c|c|c|}
\hline \multirow[b]{2}{*}{ Level } & \multicolumn{4}{|l|}{ Factors } \\
\hline & $\begin{array}{l}\text { Sodium Alginate Concentration } \\
\text { (A) } \\
\%\end{array}$ & $\begin{array}{l}\mathrm{CaCl}_{2} \text { Concentration } \\
\text { (B) } \\
\%\end{array}$ & $\begin{array}{l}\text { Glutaraldehyde Concentration } \\
\text { (C) } \\
\%\end{array}$ & $\begin{array}{l}\text { Ratio of Sodium Alginate and } \\
\text { Alliinase in volumn } \\
\text { (D) }\end{array}$ \\
\hline 1 & 2.5 & 3.0 & 0.75 & $4: 1$ \\
\hline 2 & 3.0 & 4.0 & 1.0 & $4: 2$ \\
\hline 3 & 3.5 & 5.0 & 1.5 & $4: 3$ \\
\hline
\end{tabular}

Table 1: Orthogonal factor table of immobilized Alliinase.

Nine experiments with a combination of different processing conditions were generated through this experimental design. Beads of immobilized Alliinase were produced according to the methods of Stoll and Seeback with slight modifications [4]. The finished beads were washed twice with distilled water and stored at $4^{\circ} \mathrm{C}$ in $10 \mathrm{~mL}$ of a 20 mM HEPES buffer (pH 6.5), containing $0.1 \mathrm{M} \mathrm{CaCl}_{2}$.

\section{Flavouring chemicals released from shallots by free and immobilized Alliinase}

The flavouring precursors were extracted first. 250 peeled shallots were mixed with deionized water in the ratio of $1: 1$. The mixed liquid was microwave-treated for $3 \mathrm{~min}$ at $300 \mathrm{~W}$, then homogenized by a homogenizer. The crushed shallot liquid was vacuum- distilled at $95^{\circ} \mathrm{C}$ for $100 \mathrm{~min}$, with a rotating speed of $75 \mathrm{rpm}$. The distilled liquid was 
mixed with petroleum ether thoroughly, then remained in the separatory funnel. The petroleum ether in the upper ether layer was recycled in the rotary evaporator at $40^{\circ} \mathrm{C}$. The flavouring precursor residue was dissolved in ethanol and stored at $4^{\circ} \mathrm{C}$. The flavouring chemicals were released from the flavouring precursors by free Alliinase and immobilized Alliinase following the method of Selby et al. [13].

\section{Statistical analysis}

Measurements were repeated three times. Data are presented as the average of three samples per trial with standard deviation of the mean. A trial refers to an independent experiment with multiple replicates of samples, rather than multiple analysis of the sample. Data was subjected to one-way analysis of variance (ANOVA) and Least Significant Difference (LSD) test using Minitab Statistical Software (Version 15). Significant difference was judged statistically by the F value at a probability $(\mathrm{p})$ below 0.05 .

\section{Results and Discussions}

\section{Characterization of Alliinase extracted from shallots}

Determination of the molecular weights of Alliinase: First and foremost, the molecular weight of Alliinase extracted from shallots was determined in this study. The different molecular weights of Alliinase are shown after extraction and purification. The molecular weights of extracted Alliinase were scattered between about $20 \mathrm{kDa}$ and $50 \mathrm{kDa}$ (line 3 of Figure 4). However, when the crude Alliinase was further purified by Sephadex G-75, a single band with a molecular weight of about $50 \mathrm{kDa}$ appeared (line 1 of Figure 4). This result indicated that the Alliinase had been fully purified after treatment with Sephadex G-75. Hence it was qualified to be used in the following study.

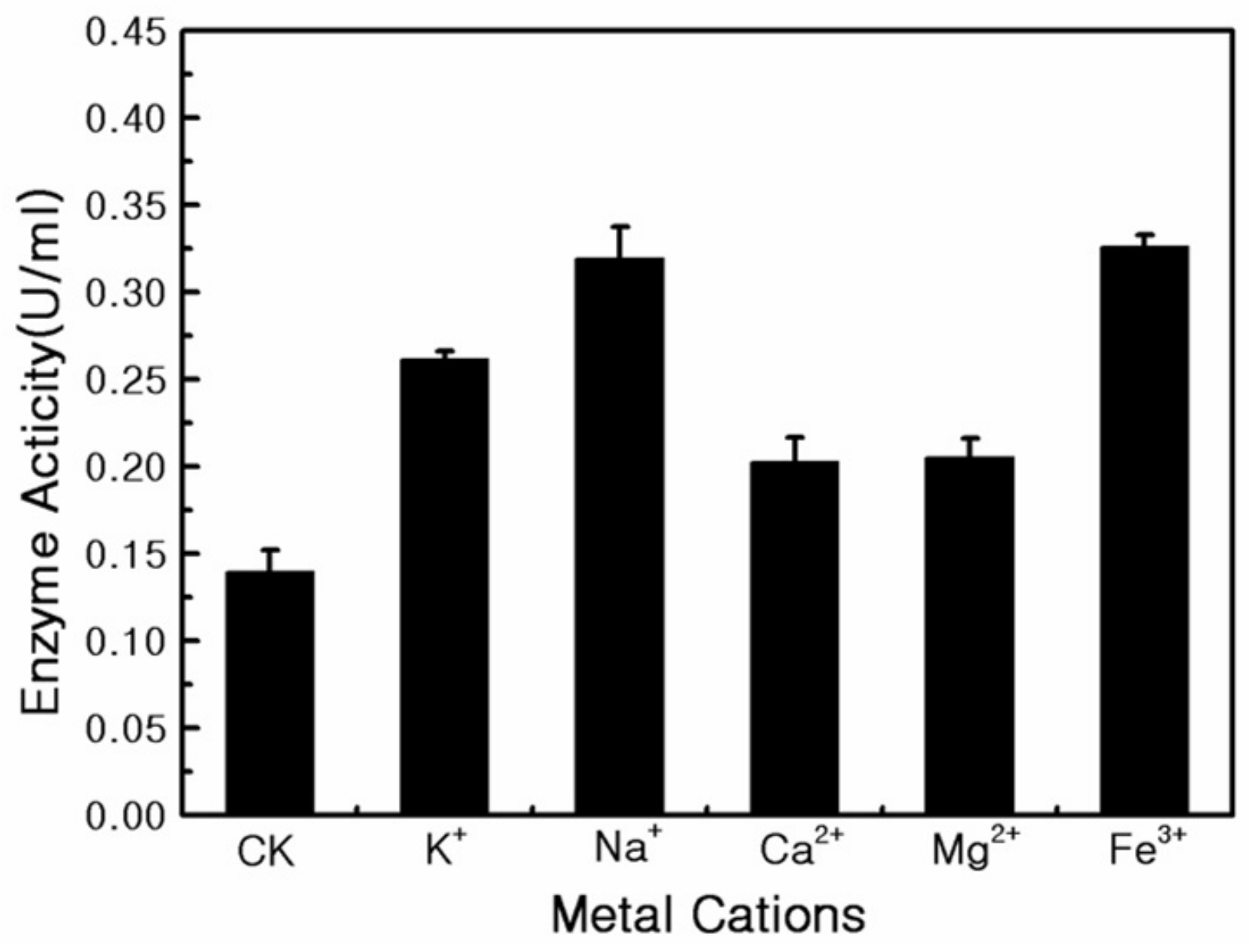

Figure 4: Effect of metals on Alliinase activity.

Determination of the optimum working conditions $(\mathrm{pH}$ and temperature) of Alliinase: The effect of temperature and $\mathrm{pH}$ on the enzyme activity of extracted Alliinase is demonstrated in Figure 2. It can be seen that the optimum conditions for the enzyme activity of Alliinase are a temperature of $40^{\circ} \mathrm{C}$ and a $\mathrm{pH}$ of 8 . Imai etal. reported that the Alliinase extracted from onion has a wide optimal $\mathrm{pH}$ range ( $\mathrm{pH} 5-8$ ) but a sharp optimum temperature of about $37^{\circ} \mathrm{C}$ [14]. Figure 2 is in line with this statement, though the Alliinase in this study was produced from a different source of shallots. 
Page 6 of 8

Kinetic analysis of Alliinase produced from shallots: MichaelisMenten kinetics is one of the best-known models of enzyme kinetics. The Michaelis-Menten equation is an important reflection of enzyme efficiency. The Michaelis-Menten equation of Alliinase extracted from shallots was determined in Figure 2, under the optimum conditions of $\mathrm{pH} 8$ and $40^{\circ} \mathrm{C}$. Figure $2 \mathrm{~A}$ shows the effect of alliin concentration on the reaction rate of Alliinase. The rapid increase in reaction rate can be seen when the substrate concentration is below $6 \mathrm{mmol} / \mathrm{L}$. However, this increase reached a plateau when the substrate concentration went above $6 \mathrm{mmol} / \mathrm{L}$. The Lineweaver-Burk plot was used to demonstrate the linear relationship between $1 / \mathrm{V}$ and $1 / \mathrm{S}$. The slope was $\mathrm{km} / \mathrm{V}_{\max }$. The determined Michaelis-Menten equation is $y=1.85056 \mathrm{x}+0.9204$.

The effect of metals on the enzyme activity of purified Alliinase produced from shallots: As Alliinase belongs to the family of Lyase, different metals that are typical enzyme activators for lyasewere used in this study. Figure 4 showed the effect of several metals on the purified Alliinase produced from shallots. It can be seen that $\mathrm{Fe}^{2+}$ demonstrated the highest effect of about $0.35 \mathrm{U} / \mathrm{ml}$, which is about 0.2 $\mathrm{U} / \mathrm{ml}$ higher than the enzyme without an activator $(0.14 \mathrm{U} / \mathrm{ml})$.
Among all the metal cations, $\mathrm{Ca}^{2+}$ showed the lowest impact of about $0.2 \mathrm{U} / \mathrm{ml}$. However, it is still significantly higher than the enzyme activity of Alliinase (A) without a metal activator.

\section{Immobilization of Alliinase extracted from shallots}

Optimization of processing conditions for immobilization of Alliinase extracted from shallots: Table 2 shows the impact of different combinations of processing conditions on the efficiency of immobilization. The $\mathrm{R}$ values show the impact of the four variables on the efficiency of immobilization; from high to low are $\mathrm{D}$ (the ratio of sodium alginate solution and Alliinase solution by volume), A (the concentration of sodium alginate solution), C (Glutaraldehyde concentration) and $\mathrm{B}(\mathrm{CaCl} 2$ concentration). It can be determined from the $\mathrm{K}$ values in Table 2 that the optimum processing conditions are $\mathrm{A} 1 \mathrm{~B} 2 \mathrm{C} 1 \mathrm{D} 3$, where the sodium alginate concentration is $2.5 \%$, the $\mathrm{CaCl}_{2}$ concentration is $4.0 \%$, the Glutaraldehyde concentration is $0.75 \%$ and the ratio of sodium alginate solution and Alliinase solution by volume is $4: 3$. The immobilized Alliinase was produced using these optimum conditions and used for the next part of the study.

\begin{tabular}{|c|c|c|c|c|c|c|}
\hline Experiment order & A & B & C & D & $\begin{array}{l}\text { Ratio of } \\
\text { Alliinase } \%\end{array}$ & immobilized \\
\hline 1 & 1 & 1 & 1 & 1 & 66.61 & \\
\hline 2 & 1 & 2 & 2 & 2 & 80.36 & \\
\hline 3 & 1 & 3 & 3 & 3 & 89.81 & \\
\hline 4 & 2 & 1 & 2 & 3 & 81.94 & \\
\hline 5 & 2 & 2 & 3 & 1 & 59.37 & \\
\hline 6 & 2 & 3 & 1 & 2 & 73.89 & \\
\hline 7 & 3 & 1 & 3 & 2 & 75.73 & \\
\hline 8 & 3 & 2 & 1 & 3 & 88.99 & \\
\hline 9 & 3 & 3 & 2 & 1 & 61.01 & \\
\hline K1 & 236.78 & 224.27 & 229.49 & 186.98 & & \\
\hline K2 & 215.20 & 228.72 & 223.31 & 229.98 & & \\
\hline K3 & 225.73 & 224.71 & 224.90 & 260.74 & & \\
\hline k1 & 78.93 & 74.76 & 76.50 & 62.33 & & \\
\hline k2 & 71.73 & 76.24 & 74.44 & 76.66 & & \\
\hline k3 & 75.24 & 74.90 & 74.97 & 86.91 & & \\
\hline $\mathrm{R}$ & 7.20 & 1.48 & 2.06 & 24.59 & & \\
\hline Optimum level & A1 & B2 & C1 & D3 & & \\
\hline Order of influence & \multicolumn{4}{|c|}{$D>A>C>B$} & & \\
\hline
\end{tabular}

Table 2: Orthogonal experiment.

The capacity to release flavouring chemicals from shallots by free and immobilized Alliinase: The categories and percentages of flavouring chemicals released by free and immobilized Alliinase from shallots were examined using gas chromatography-mass spectormetry. The immobilized Alliinase produced by the optimized conditions, shown in Table 2, were used in this examination. Table 3 shows that both the categories and the percentages of the flavouring chemicals released from both forms of Alliinase are similar. The only difference is that the immobilized Alliinase seemed to release extra Glutaraldehyde. However, this is because Glutaraldehyde is the raw material used to produce immbolibized Alliinase. There are 36 different flavouring chemicals released by both free and immobilized Alliinase. These 
Citation: Zeng Q, Veng A, Kong L, He S (2017) Characterization and Immobilization of Purified Alliinase Produced from Shallots. J Bioprocess

results demonstrate that although the Alliinase was encapsulated by alginate, the development of the immbolibized Alliinase does not impair its ability to release flavour.

\begin{tabular}{|c|c|c|c|c|c|c|c|}
\hline \multirow{2}{*}{ Number } & \multirow{2}{*}{$\begin{array}{l}\text { Retention time } \\
\text { (min) }\end{array}$} & \multirow{2}{*}{ Compounds } & \multirow{2}{*}{$\begin{array}{l}\text { Molecular } \\
\text { weights (Da) }\end{array}$} & \multirow{2}{*}{$\begin{array}{l}\text { Molecular } \\
\text { formula }\end{array}$} & \multicolumn{3}{|c|}{$\begin{array}{l}\text { Percentage } \\
\%\end{array}$} \\
\hline & & & & & A & B & C \\
\hline 1 & 4.87 & Propyl hydrodisulfide & 108 & $\mathrm{C}_{3} \mathrm{H}_{8} \mathrm{~S}_{2}$ & 0.89 & 0.76 & 0.69 \\
\hline 2 & 5.78 & Thiophene, 2,5-dimethyl- & 112 & $\mathrm{C}_{6} \mathrm{H}_{8} \mathrm{~S}$ & 0.13 & 1.27 & 1.45 \\
\hline 3 & 6.17 & Allyl Propyl Sulfide & 116 & $\mathrm{C}_{6} \mathrm{H}_{12} \mathrm{~S}$ & 3.53 & 5.60 & 5.08 \\
\hline 4 & 6.30 & (Z)-1-Methyl-2-(prop-1-en-1-yl) disulfane & 120 & $\mathrm{C}_{4} \mathrm{H}_{10} \mathrm{~S}_{2}$ & 1.01 & 1.25 & 0.51 \\
\hline 5 & 6.48 & (E)-1-Methyl-2-(prop-1-en-1-yl) disulfane & 120 & $\mathrm{C}_{4} \mathrm{H}_{10} \mathrm{~S}_{2}$ & 1.25 & 2.23 & 3.15 \\
\hline 6 & 7.11 & Dimethyl trisulfide & 126 & $\mathrm{C}_{2} \mathrm{H}_{6} \mathrm{~S}_{3}$ & 3.85 & 4.13 & 4.12 \\
\hline 9 & 10.13 & (E)-1-(Prop-1-en-1-yl)-2-propyldisulfane & 148 & $\mathrm{C}_{6} \mathrm{H}_{12} \mathrm{~S}_{2}$ & 1.46 & 0.75 & 0.30 \\
\hline 10 & 10.25 & 1-((E)-Prop-1-en-1-yl)-2-((Z)-prop-1-en-1-yl) disulfane & 146 & $\mathrm{C}_{6} \mathrm{H}_{10} \mathrm{~S}_{2}$ & 0.38 & 0.20 & 0.22 \\
\hline 12 & 10.87 & Trisulfide, methyl propyl & 154 & $\mathrm{C}_{4} \mathrm{H}_{10} \mathrm{~S}_{3}$ & 3.98 & 2.65 & 2.17 \\
\hline 13 & 11.07 & (E)-1-Methyl-3-(prop-1-en-1-yl) trisulfane & 152 & $\mathrm{C}_{4} \mathrm{H}_{8} \mathrm{~S}_{3}$ & 6.38 & 8.82 & 7.56 \\
\hline 14 & 12.19 & Tetrasulfide, dimethyl & 158 & $\mathrm{C}_{2} \mathrm{H}_{6} \mathrm{~S}_{4}$ & 7.52 & 9.28 & 8.72 \\
\hline 15 & 13.98 & (E)-Prop-1-en-1-yl propanedithioate & 146 & $\mathrm{C}_{6} \mathrm{H}_{10} \mathrm{~S}_{2}$ & 0.42 & & \\
\hline 16 & 14.23 & Trisulfide, dipropyl & 182 & $\mathrm{C}_{6} \mathrm{H}_{14} \mathrm{~S}_{3}$ & 1.30 & 0.87 & 0.94 \\
\hline 17 & 14.29 & (E)-1-(Prop-1-en-1-yl)-3-propyltrisulfane & 180 & $\mathrm{C}_{6} \mathrm{H}_{12} \mathrm{~S}_{3}$ & 2.56 & 2.33 & 2.83 \\
\hline 18 & 14.50 & (E)-1-Allyl-3-(prop-1-en-1-yl) trisulfane & 178 & $\mathrm{C}_{6} \mathrm{H}_{10} \mathrm{~S}_{3}$ & 3.53 & 5.60 & 5.08 \\
\hline 19 & 14.69 & 1,3-Di((E)-prop-1-en-1-yl) trisulfane & 178 & $\mathrm{C}_{6} \mathrm{H}_{10} \mathrm{~S}$ & 0.68 & 1.43 & 1.36 \\
\hline 20 & 15.05 & 5-Methyl-1,2,3,4-tetrathiane & 170 & $\mathrm{C}_{3} \mathrm{H}_{6} \mathrm{~S}_{4}$ & 1.38 & 1.81 & 1.60 \\
\hline 21 & 15.59 & Pyridylhydroxymethanesulfonic acid & 189 & $\mathrm{C}_{6} \mathrm{H}_{7} \mathrm{NO}_{4} \mathrm{~S}$ & & 3.26 & 3.29 \\
\hline 22 & 15.60 & Tetrasulfide, dipropyl & 214 & $\mathrm{C}_{6} \mathrm{H}_{14} \mathrm{~S}_{4}$ & 2.91 & & \\
\hline 23 & 19.09 & Tetrasulfide, dipropyl & 214 & $\mathrm{C}_{6} \mathrm{H}_{14} \mathrm{~S}_{4}$ & 7.36 & 7.43 & 7.58 \\
\hline 24 & 19.55 & trans-3,6-Diethyl-1,2,4,5-tetrathiane & 212 & $\mathrm{C}_{6} \mathrm{H}_{12} \mathrm{~S}_{4}$ & 1.76 & 6.01 & 6.74 \\
\hline 25 & 20.20 & 4,6-Diethyl-1,2,3,5-tetrathiolane & 212 & $\mathrm{C}_{6} \mathrm{H}_{12} \mathrm{~S}$ & 2.92 & 2.92 & 3.55 \\
\hline 26 & 25.40 & 4,7-Diethyl-1,2,3,5,6-pentathiepane & 244 & $\mathrm{C}_{6} \mathrm{H}_{12} \mathrm{~S}_{5}$ & 3.28 & 4.39 & 4.28 \\
\hline 27 & 4.40 & 2-Pentenal, 2-methyl- & 98 & $\mathrm{C}_{6} \mathrm{H}_{10} \mathrm{O}$ & 2.78 & 2.70 & 1.53 \\
\hline 28 & 5.52 & Glutaraldehyde & 100 & $\mathrm{C}_{5} \mathrm{H}_{8} \mathrm{O}_{2}$ & & & 2.00 \\
\hline 29 & 14.52 & 5-Benzofurazancarboxylic acid, 1-oxide & 180 & $\mathrm{C}_{7} \mathrm{H}_{4} \mathrm{~N}_{2} \mathrm{O}_{4}$ & 3.53 & 5.60 & 6.08 \\
\hline 32 & 16.40 & 3(2H)-Furanone, 2-hexyl-5-methyl- & 182 & $\mathrm{C}_{11} \mathrm{H}_{18} \mathrm{O}_{2}$ & 6.31 & 8.81 & 8.41 \\
\hline 33 & 20.65 & $3(2 \mathrm{H})$-Furanone, 5-methyl-2-octyl- & 210 & $\mathrm{C}_{13} \mathrm{H}_{22} \mathrm{O}_{2}$ & & 3.76 & 4.15 \\
\hline 34 & 25.81 & Octadecane & 254 & $\mathrm{C}_{18} \mathrm{H}_{38}$ & 3.95 & 2.89 & 3.93 \\
\hline 35 & 27.04 & n-Hexadecanoic acid & 256 & $\mathrm{C}_{16} \mathrm{H}_{32} \mathrm{O}_{2}$ & 0.66 & 0.23 & 0.73 \\
\hline 36 & 27.14 & Dibutyl phthalate & 278 & $\mathrm{C}_{16} \mathrm{H}_{22} \mathrm{O}_{4}$ & 1.41 & 2.77 & 2.30 \\
\hline
\end{tabular}




\begin{tabular}{|l|l|l|l|l|l|l|}
\hline 37 & 27.37 & $\begin{array}{l}\text { Phenanthrene, 7-ethenyl-1,2,3,4,4a,4b,5,6,7,9,10,10a- } \\
\text { dodecahydro-1,1,4a,7-tetramethyl-, } \\
\text { 4b.beta.,7.beta.,10a.beta.)]- }\end{array}$ & $\mathrm{C}_{20} \mathrm{H}_{32}$ & 0.87 & 0.59 \\
\hline
\end{tabular}

Table 3: The compositions of volatile compounds from shallot essential oil.

\section{Conclusions}

This study comprehensively analysed Alliinase extracted and purified from shallots. It found that the molecular weight of purified Alliinase was about $50 \mathrm{kDa}$ with optimal working conditions of $\mathrm{pH} 8$ and $40^{\circ} \mathrm{C}$. Metals significantly affected Alliinase in a positive way. Using alginate to immobilize Alliinase, the optimized conditions were: sodium alginate concentration of $2.5 \%, \mathrm{CaCl}_{2}$ concentration of $4.0 \%$, Glutaraldehyde concentration of $0.75 \%$ and a ratio of sodium alginate solution and Alliinase solution by volume of 4:3. Both free Alliinase and immobilized Alliinase were able to release 36 flavouring chemicals from flavouring precursors with the similar ratio. This showed that the immobilization process using alginate did not reduce the flavour releasing ability of free Alliinase. This study provided comprehensive information to assist with future commercial applications of Alliinase produced from shallots.

\section{Acknowledgement}

The authors appreciate the financial support from the Science and Technology plan of Guangdong Province (Project No.: 2014A010107029) and Guangzhou City (Project No.: 201604020089).

\section{References}

1. Orga Y, Ishiwata K, Iwashita Y, Kazuo TS (2005) Simultaneous speciation of selenium and sulfur species in selenized odourless garlic and shallot by HPLC-inductively coupled plasms-mass spectrometry and electrospray ionization-tandem mass spectrometry. Journal of Chromatography 1093 : 118-125.

2. Keusgen M, Schulz H, Glodek J, Krest I, Kruger H, et al. (2002) Characterization of some Allium Hybrids by aroma precursors, aroma profiles, and alliinase activity. Journal of Agricultural and Food Chemistry 50: 2884-2890.
3. Krest I, Glodek J, Keusgen M (2000) Cysteine sulfoxides and allinase activity of some allium species. Journal of Agricultural and Food Chemistry 48: 3753-3760.

4. Stoll A, Seebeck W (2006) Chemical investigations on allin, the specific principle of garlic. Advances in Enzymology and Related Areas of Molecular Biology 11.

5. Nock LP, Mazelis M (1986) The C-S lyases of higher plants: preparation and properties of homogenous alliin lyase from garlic. Archives of Biochemistry and Biophysics 249: 27-33.

6. Yan M, Zhen X, Chan X, De-ping G (2010) Research Progress of Bioactive Components in Garlic. Food Science 12: 45-48.

7. Ko JA, Lee YL, Jeong HJ, Park HJ (2012) Preparation of encapsulated alliinase in alginate microparticles. Biotechnology Letters 34: 515-518.

8. Zhou J, Wang J (2009) Immobilization of alliinase with a water solubleinsoluble reversible N-succinyl-chitosan for allicin production. Enzyme and Microbial Technology 45: 299-304.

9. Islam R, Kite J, Baker AS, Ching J (2006) Affinity purification of hen egg lysozyme using sephadex G75. African Journal of Biotechnology 5: 62-65.

10. Schwinner S, Mazelis M (1963) Characterization of alliinase of Allium cepa. Archives of Biochemistry and Biophysics 100: 66-73.

11. He S, Franco C, Zhang W (2010) Characterization of processing coproducts of Atlantic salmon and Yellowtail kingfish harvested in Australia. International Journal of Food Science and Technology 46: 1898-1904.

12. Lawson LD, Wang Z (2001) Low allicin release from garlic supplements: a major problem due to the sensitivities of alliinase activity. Journal of Agricultural and Food Chemistry 49: 2592-2599.

13. Selby C, Turnbullf A, Collin H (1980) Comparison of the onion plant and onion tissue cluture II. Stimulation of flavour precursor synthesis in onion tissue cultures. New Phytologist 84: 307-312.

14. Imai S, Akita K, Tomotake M, Sawada H (2006) Model studies on precursor system generating blue pigment in onion and garlic. Journal of Agricultural and Food Chemistry 54: 848-852. 